\title{
Antibiotic prescribing pattern in paediatric in patients with first time wheezing
}

Soumya Patra ${ }^{1,2^{*}}$, Varinder Singh ${ }^{1}$, Harish K Pemde ${ }^{1}$ and Jagdish Chandra ${ }^{1}$

\begin{abstract}
Background: Acute wheezers for the first time in life are an important target group for efforts aimed at reducing unnecessary antibiotic use.

Objective: To evaluate the effect of clinical, laboratory and radiological data on the decision to prescribe antibiotics to paediatric patients with first time wheezing as well as to seek criteria that would justify antibiotic use.

Methods: A prospective study was made of 47 previous healthy children admitted to our hospital with first time wheezing in life between October 2008- March 2009. All the patients were treated as per the treating unit's protocol with oxygen, bronchodilators with or without antibiotics. The cases were analyzed after discharge and the characteristics of those treated with antibiotics $(n=23)$ were compared with those who were not $(n=24)$ and analyzed statistically to find the predictors for antibiotic usage.
\end{abstract}

Results: The mean age of the study groups was $5.8(+/-5.1)$ months. Among the clinical and investigational parameters, presence of predominant crackles and abnormalities on radiograph were the major determinants for antibiotic usage. There were no significant differences in final outcome between these groups.

Conclusion: Antibiotic usage in first time wheezers is still quite prevalent. Presence of crackles and radiological abnormalities often prompt the usage of antibiotics in such cases.

Keywords: Antibiotic, acute bronchiolitis, wheezing

\section{Introduction}

Bronchiolitis is a commonly caused viral infection and is the predominant cause of acute wheezing in infants. It is characterized by acute inflammation, oedema, and necrosis of epithelial cells lining small airways, increased mucus production, and bronchospasm. The most common etiology is the respiratory syncytial virus (RSV), with the highest incidence of RSV infection occurring between December and March [1]. Therapies currently in the treatment of Bronchiolitis include bronchodilator, nasal clearance, ribavarine and/or corticosteroids. While bronchiolitis is an important cause of wheezing in young children, it can also occur, albeit less commonly, with bacterial infections as well. Further, the WHO driven national guidelines on clinical diagnosis and management of pneumonia in the developing nations

\footnotetext{
* Correspondence: dr_soumyapatra@rediffmail.com

'Department of Paediatrics, Lady Hardinge Medical College \& associated

Kalawati Saran Children's Hospital, New Delhi, India

Full list of author information is available at the end of the article
}

suggest that fewer than five children with tachypnoea beyond a certain rates should be clinically diagnosed and managed as pneumonia. Therefore antibiotics are often used in the management of first time wheezer in our country and the children with wheezing caused by acute bronchiolitis represent an important target group for efforts aimed at reducing unnecessary antibiotic use. The pediatricians would justify the use of antibiotics in bronchiolitis because it is difficult to differentiate from acute pneumonia or because of the risk of secondary bacteremia or pneumonia in the cases with viral bronchiolitis. Some of these concerns are not substantiated as a prospective study showed that none of their patients with bronchiolitis had bacteraemia [2]. Antibiotic may only be necessary when bacterial pneumonia is suspected e.g. high fever, toxicity, leucocytosis and lobar infiltrate. It has been repeatedly shown that inappropriate use of antibiotic changes the course of the disease and promotes the development of resistant organism but very few studies have been done in developing 
countries in this regard [3]. This study was conducted to evaluate the effect of clinical, laboratory and radiological data on the decision to prescribe antibiotics to paediatric patients with first time wheezing as well as to seek criteria that would justify antibiotic use.

\section{Subjects and methods}

This was a prospective observational study done in the Department of paediatrics of a tertiary Care centre at New Delhi, between October'2008 to March'2009.

\section{Study Design}

It was a prospective observational study.

\section{Inclusion criteria}

All the children below two years of age admitted with first time wheezing in life were our study population.

\section{Exclusion criteria}

If a child had: i) atopic conditions ii) congenital heart disease and/or iii) known immunodeficiency, (s) he was excluded from the study.

\section{Methodology}

Structured questionnaire were filled up after taking a detailed history and thorough examination of the child by the investigator. All the patients were subjected to initial investigations such as complete Hemogram, Creactive protein $(\mathrm{CRP})$, oxygen saturation $(\mathrm{SpO} 2)$ and/or Arterial blood gases (where necessary) and Frontal view Chest Radiograph. Supportive treatment with Oxygen $(\mathrm{SpO} 2<92 \%)$ and nebulisation with adrenaline $(0.1 \mathrm{ml} /$ $\mathrm{kg}$ of 1:1000 solution) or salbutamol solution $(0.15 \mathrm{mg} /$ $\mathrm{kg}$ ) were given at admission and 3-6 hourly after that according to the clinical situation. The cases were followed up three times in 48 hours. The policy of the unit was not universal prescription of antibiotics and the treating/admitting pediatrician could use antibiotics should the clinical or investigative profile suggest the possibility of a bacterial infection (Figure 1). Structured follow- up format included time to resolution of fever, respiratory difficulty and tachypnea, rhonchi and chest indrawing. Criteria for discharging the patient were -feeding adequately, no respiratory distress and no requirement of $\mathrm{O} 2$ therapy. The patients were followedup seven days after discharge in the outpatient department for any recurrence or persistence of symptoms.

The case proformas were evaluated at the end of follow up and the study subjects were divided into two groups- those who received antibiotics (Group 1) and those who did not (Group 2) (Figure 1). The clinical variables between the groups were compared. As the study involved evaluation of the case data after management of the case, no ethical clearance was needed as per

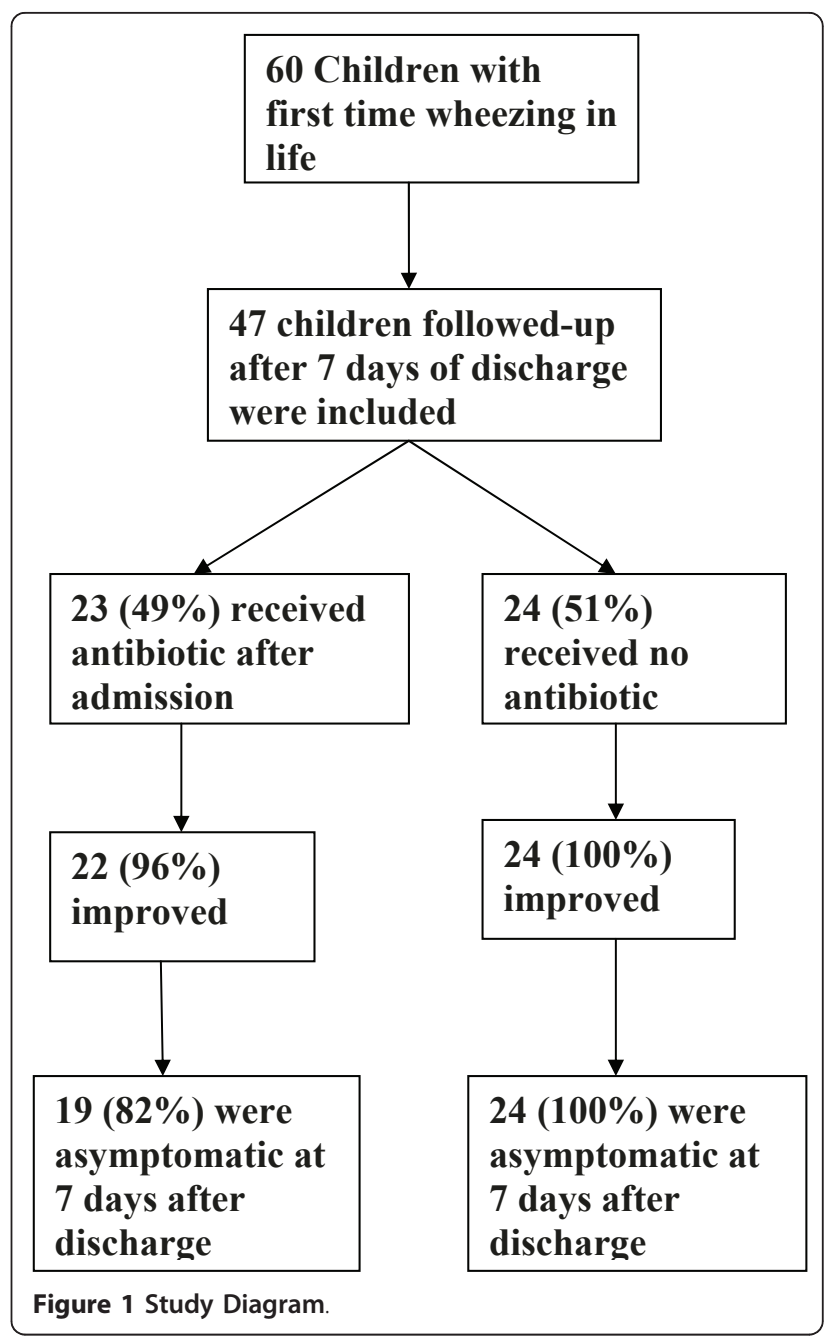

Institutional policy. Informed consent of the parents was however taken before enrolling in the study.

\section{Statistical analysis}

Chi-square test was used for statistical analysis using SPSS software and P-value less than $<0.05$ was considered as significant result.

\section{Results}

Sixty successive cases with first time wheezer under two years of age were enrolled. Among these, forty-seven children who could be followed up till after seven days of discharge were finally included in this study. Rests were lost to follow-up. Most (70\%) of these cases were below six months of age (mean age 5.8 months +5.1 ; range 1-24 months). Male children (66\%) outweighed the females in number. The prodrome of cough, coryza and fever (85\%) along with respiratory distress (96\%) was the common presenting feature. Among the presenting signs, all of them had tachypnea and rhonchi in 
Table 1 Comparison between clinical and laboratory parameters at admission

\begin{tabular}{llll}
\hline Clinical \& Laboratory Parameter & $\begin{array}{l}\text { Antibiotic group } \\
(\mathbf{n}=\mathbf{2 3})\end{array}$ & $\begin{array}{l}\text { Non-antibiotic group } \\
(\mathbf{n}=\mathbf{2 4})\end{array}$ & $\mathbf{P}$ value/(95\% Cl) \\
\hline Mean age & 5.3 month (+/- 5.2) & 6.3 months (+/- 4.9) & $P>0.1(1-11)$ \\
\hline Viral prodrome & $18(78 \%)$ & $23(96 \%)$ & $P=0.17(7-19)$ \\
\hline Fever & $15(65 \%)$ & $09(38 \%)$ & $P=0.1(-3-10)$ \\
\hline Respiratory distress & $23(100 \%)$ & $23(96 \%)$ & $P=0.9(21-43)$ \\
\hline Tachypnea & $23(100 \%)$ & $23(96 \%)$ & $P=0.9(9-17)$ \\
\hline Chest indrawing & $16(70 \%)$ & $12(50 \%)$ & $P=0.28(2-13)$ \\
\hline Rhonchi & $23(100 \%)$ & $24(100 \%)$ & $P=0.05(1-23)$ \\
\hline Crepitation & $18(78 \%)$ & $10(42 \%)$ & $P=0.02(5-13)$ \\
\hline Leucocytosis & $16(70 \%)$ & $11(46 \%)$ & $P=0.18(14-25)$ \\
\hline$>15,000 /$ cmm) & $16(70 \%)$ & $04(17 \%)$ & $P=0.96(17-35)$ \\
\hline Abnormal Chest X-ray & $02(09 \%)$ & $01(04 \%)$ & $(-9-+8)$ \\
\hline Increased C-reactive & & & $P$ \\
protein $>1$ mg/lit.) & & & $P$ \\
\hline
\end{tabular}

the chest. Among these, 49\% (23/47) had received oral or intravenous antibiotics sometime during hospital stay and while about half didn't receive antibiotics. The clinical, laboratory and radiological parameters at admission, course during hospital stay and final outcome of the two groups was compared (Tables 1, 2, 3).

Chest skiagram was done in all cases at admission day and parenchymal opacities like patchy infilterates, segmental atelectasis, and segmental/lobar consolidation were seen in $40 \%$ of cases. It was repeated in few cases which did not improve with therapy. Lower mean age at presentation, predominant crackles in the chest and abnormalities on skiagrams like infiltrates, atelectasis, and segmental consolidation were more often associated with antibiotic usage. There was no case with cyanosis or saturation of oxygen $<95 \%$.

The clinical parameters resolved earlier during hospital stay in the Group 2 compared to antibiotic group though the difference between the two groups was not statistically significant.

Almost all patients (96\%) of antibiotic treated group and all patients with non-antibiotic group of acute bronchiolitis had improved with treatment. Though the

Table 2 Comparison of the course during hospital stay between the groups

\begin{tabular}{lccccc}
\hline $\begin{array}{l}\text { Clinical } \\
\text { parameter }\end{array}$ & \multicolumn{2}{c}{ Antibiotic group } & \multicolumn{2}{c}{$\begin{array}{c}\text { Non-antibiotic } \\
\text { group }\end{array}$} & $\begin{array}{c}\mathbf{P} \\
\text { value }\end{array}$ \\
\hline $\begin{array}{c}\text { After } \mathbf{2 4} \\
\mathbf{h}\end{array}$ & $\begin{array}{c}\text { After } \mathbf{4 8} \\
\mathbf{h}\end{array}$ & $\begin{array}{c}\text { After } \mathbf{2 4} \\
\mathbf{h}\end{array}$ & $\begin{array}{c}\text { After } \mathbf{4 8} \\
\mathbf{h}\end{array}$ & \\
\hline Fever & $08 / 15$ & $06 / 15$ & $04 / 09$ & 00 & $\mathrm{P}>0.5$ \\
\hline $\begin{array}{l}\text { Respiratory } \\
\text { distress }\end{array}$ & $20 / 23$ & $05 / 23$ & $13 / 23$ & $02 / 23$ & $\begin{array}{c}\mathrm{P}= \\
0.09\end{array}$ \\
\hline Tachypnea & $14 / 23$ & $07 / 23$ & $10 / 23$ & $03 / 23$ & $\mathrm{P}>0.5$ \\
\hline Rhonchi & $23 / 23$ & $21 / 23$ & $24 / 24$ & $11 / 24$ & $\mathrm{P}>0.1$ \\
\hline
\end{tabular}

mean hospital stay was more in antibiotic treated group and $18 \%(4 / 23)$ of them had respiratory symptoms at seven days follow-up, but the difference between the two groups was not statistically significant.

\section{Discussion}

In Europe, Australia and North America, about 3\% of each year's birth cohort is admitted with bronchiolitis every winter in their infancy [4]. In this study $70 \%$ of children were aged below six months and majority of them were male which is in conformity with observations all over the world [5]. Most clinicians assess bronchiolitis on the basis of history and physical examination [1]. Respiratory distress was the most common starting symptoms in our series, though literatures has described fever as being very common in initial phase of illness but it largely disappears by the time of hospitalization as a characteristic feature of the disease [6]. The antibiotic treated group more often had crackles and it appears that the presence of crackles in such cases is often considered as a sign of pneumonia by the clinicians prompting the use of antibiotics. In our study,

Table 3 Comparison between final outcomes within the groups according to their receiving status in patients with first time wheezer

\begin{tabular}{lccc}
\hline Outcome & $\begin{array}{c}\text { Antibiotic } \\
\text { group }\end{array}$ & $\begin{array}{c}\text { Antibiotic } \\
\text { group }\end{array}$ & $\begin{array}{c}\text { Non- } \\
\text { antibiotic }\end{array}$ \\
\hline (n = 23) & $(\mathbf{n}=\mathbf{2 4 )}$ & \\
\hline Improved & $22(96 \%)$ & $24(100 \%)$ & $P=>0.5$ \\
\hline Deteriorated & 01 & 00 & $P=>0.1$ \\
\hline Mean Hospital stay & $5.86(+/-3.2$ d) & $4.12(+/-2.6 \mathrm{~d})$ & $\mathrm{P}>0.05$ \\
\hline $\begin{array}{l}\text { Asymptomatic at } \\
\text { follow- } \\
\text { up after } 7 \text { days }\end{array}$ & $19(82 \%)$ & $24(100 \%)$ & $\mathrm{P}=0.19$ \\
\hline
\end{tabular}


patients who were sick or had abnormal parenchymal opacities on chest skiagram in the form of infilterates, segmental atelectasis and/or consolidation also were more likely to receive antibioitics. This may not have been necessarily justified because the markers like leucocytosis, increased CRP levels and lobar consolidations often considered suggestive of bacterial infection have also been reported in up to $30 \%$ of infants with viral bronchiolitis (most commonly in infants with severe disease) [7]. Many clinicians agree that bacterial pneumonia in infants with bronchiolitis without consolidation is unusual [8] and consolidation by it self does not allow for adequate identification of patients with bacterial infection $[9,10]$. Consolidation was present in only $7 \%$ of our cases but overall parenchymal opacities including patchy infiltration were reported more numerously than others $[11,12]$.

Several studies suggest that the presence of consolidation and atelectasis on a chest radiograph is associated with increased risk for severe disease $[13,14]$ while others found no correlation between chest radiograph findings and baseline severity of disease [15]. Routine radiography in children with bronchiolitis is not recommended because it is nonspecific, fraught with wrong interpretation and adds to unnecessary cost $[16,17]$.

Children with bronchiolitis frequently receive antibacterial therapy because of fever, young age, or the concern over secondary bacterial infection $[18,19]$. Our study also had similar findings. Mean hospital stay was more in antibiotic treated groups and $18 \%$ of them again came with respiratory complaints on seventh day after discharge. This is perhaps a reflection of the practice that sicker and more severely ill children are more often given presumptive antibiotic therapy. Interestingly, the final outcome between the two groups was statistically not significant. Though previous studies showed no benefit from antibacterial treatment of bronchiolitis $[18,19]$ however, the concern remains regarding the possibility of bacterial infections in young infants with wheezing; thus, antibacterial agents still continue to be used.

In our considered opinion, an important message from our findings is that universal usage of antibiotics children with first time wheezing is not needed and efforts should be made to identify test(s) with good discriminatory power to identify those who really need them.

\section{Conclusion}

The problem of antibiotic over usage amongst first time wheezer remains largely due to overlapping clinical presentations, poor laboratory and radiological discrimination and fear of missing bacterial pneumonia in sick babies. Still a significant proportion of the first time wheezers can be managed without any antibiotics. More studies with larger number of subjects are needed to clearly identify those who can be managed without antibiotics.

\section{Funding}

None

\section{Author details}

'Department of Paediatrics, Lady Hardinge Medical College \& associated Kalawati Saran Children's Hospital, New Delhi, India. ${ }^{2}$ Department of Cardiology, Sri Jayadeva Institute of Cardiovascular Sciences and Research, Bangalore, Karnataka, India.

\section{Authors' contributions}

VS planned the study, designed the protocol and corrected the manuscript. SP collected data, reviewed the literature and drafted the manuscript. HP and $\mathrm{JC}$ were involved in the management of cases. All authors approved the final version of the manuscript.

\section{Competing interests}

The authors declare that they have no competing interests.

Received: 2 April 2011 Accepted: 5 September 2011

Published: 5 September 2011

\section{References}

1. American Academy of Pediatrics- Subcommittee on diagnosis and management of bronchiolitis: Diagnosis and management of bronchiolitis. Pediatrics 2006, 118:1774-93.

2. Shay DK, Holman RC, Newman RD, Liu LL, Stout JW, Anderson LJ: Bronchiolitis associated hospitalization among US children 1980-96. JAMA 1999, 282:1440-6.

3. Majumder JU, Hossain MM, Kabir ARML: Management of bronchiolitis with or without antibiotic. Bangladesh J Child Health 2005, 29:41-5.

4. Shay DK, Holman RC, Newman RD, Lice LL, Stout JW, Anderson LJ: Bronchiolitis associated mortality and estimates of respiratory syncytial virus associated death among US children 1979-97. J Infect Dis 2001, 183:16-22.

5. Stein RT, Sherill D, Morgan WJ: Respiratory syncytial virus in early life and risk of wheeze and allergy by age 13 years. Lancet 1999, 354:541-5.

6. Goh A, Chay OM, Foo AL, Ong EK: Efficacy of bronchodilators in the treatment of bronchiolitis. Singapore Med J 1997, 38:326-8.

7. Mahabee-Gittens EM, Grupp-Phelan J, Brody AS: Identifying children with pneumonia in the emergency department. Clin Pediatr (Phila) 2005, 44:427-435.

8. Brooks AM, McBride JT, McConnochie KM, Aviram M, Long C, Hall CB: Predicting deterioration in previously healthy infants hospitalized with respiratory syncytial virus infection. Pediatrics 1999, 104:463-467.

9. Shaw KN, Bell LM, Sherman NH: Outpatient assessment of infants with bronchiolitis. Am J Dis Child 1991, 145:151-155.

10. McMillan JA, Tristram DA, Weiner LB, Higgins AP, Sandstrom C, Brandon R: Prediction of the duration of hospitalization in patients with respiratory syncytial virus infection: use of clinical parameters. Pediatrics 1988, 81:22-26.

11. Rakshi K, Couriel JM: Management of Acute bronchiolitis. Arch Dis child 1994, 71:463-9.

12. Flores $\mathrm{G}$, Horwitz Rl: Efficacy of $\mathrm{B} 2$ agonists in Bronchiolitis. Pediatrics 1997, 100:233-9.

13. Navas L, Wang E, de Carvalho V, Robinson J: Improved outcome of respiratory syncytial virus infection in a high-risk hospitalized population of Canadian children. Pediatric Investigators Collaborative Network on Infections in Canada. J Pediatr 1992, 121:348-354.

14. Wang EE, Law BJ, Stephens D: Pediatric Investigators Collaborative Network on Infections in Canada (PICNIC) prospective study of risk factors and outcomes in patients hospitalized with respiratory syncytial viral lower respiratory tract infection. J Pediatr 1995, 126:212-219.

15. Dawson KP, Long A, Kennedy J, Mogridge N: The chest radiograph in acute bronchiolitis. J Paediatr Child Health 1990, 26:209-211. 
16. Yong JH, Schuh S, Rashidi R, Vanderby S, Lau R, Laporte A, Nauenberg E, Ungar WJ: A cost effectiveness analysis of omitting radiography in diagnosis of acute bronchiolitis. Pediatr Pulmonol 2009, 44(2):122-7.

17. Schuh S, Lalani A, Allen U, Manson D, Babyn P, Stephens D, MacPhee S, Mokanski M, Khaikin S, Dick P: Evaluation of the Utility of Radiography in Acute Bronchiolitis. J of Pediatrics 2007, 150:429-433.

18. LaVia W, Marks MI, Stutman HR: Respiratory syncytial virus puzzle: clinical features, pathophysiology, treatment, and prevention. J Pediatr 1992, 121:503-510.

19. Antonow JA, Hansen K, McKinstry CA, Byington CL: Sepsis evaluations in hospitalized infants with bronchiolitis. Pediatr Infect Dis J 1998, 17:231-236

doi:10.1186/1824-7288-37-40

Cite this article as: Patra et al:: Antibiotic prescribing pattern in paediatric in patients with first time wheezing. Italian Journal of Pediatrics 2011 37:40.

\section{Submit your next manuscript to BioMed Central} and take full advantage of:

- Convenient online submission

- Thorough peer review

- No space constraints or color figure charges

- Immediate publication on acceptance

- Inclusion in PubMed, CAS, Scopus and Google Scholar

- Research which is freely available for redistribution

Submit your manuscript at www.biomedcentral.com/submit 